\title{
Early cerebral hemodynamic, metabolic, and histological changes in hypoxic-ischemic fetal lambs during postnatal life
}

\author{
Carmen Rey-Santano ${ }^{1}$, Victoria E. Mielgo ${ }^{1}$, Elena Gastiasoro ${ }^{1}$, Xabier Murgia ${ }^{1}$, Hector Lafuente ${ }^{1}$, \\ Estibaliz Ruiz-del-Yerro' ${ }^{1}$, Adolf Valls-i-Soler ${ }^{2}$, Enrique Hilario ${ }^{3}$ and Francisco J. Alvarez' \\ ${ }^{1}$ Research Unit on Experimental Respiratory Physiology, Cruces Hospital, Bizkaia, Spain \\ ${ }^{2}$ Department of Pediatrics. Cruces Hospital, Bizkaia, Spain \\ ${ }^{3}$ Department of Cell Biology and Histology, University of the Basque Country, Bizkaia, Spain
}

\section{Edited by:}

Laszlo Acsady, Institute of

Experimental Medicine, Hungary

Reviewed by:

José Miguel Blasco Ibáñez, University of Valencia, Spain

Aldina Venerosi, Istituto Superiore di Sanità, Italy

*Correspondence:

Carmen Rey-Santano, Research Unit on Experimental Physiology, Cruces

Hospital, Plaza de Cruces s/n,

Barakaldo E-48903, Bizkaia, Spain.

e-mail: macarmen.reysantano@

osakidetza.net
The hemodynamic, metabolic, and biochemical changes produced during the transition from fetal to neonatal life may be aggravated if an episode of asphyxia occurs during fetal life. The aim of the study was to examine regional cerebral blood flow (RCBF), histological changes, and cerebral brain metabolism in preterm lambs, and to analyze the role of oxidative stress in the first hours of postnatal life following severe fetal asphyxia. Eighteen chronically instrumented newborn lambs were randomly assigned to either a control group or the hypoxic-ischemic (HI) group, in which case fetal asphyxia was induced just before delivery. All the animals were maintained on intermittent positive pressure ventilation for $3 \mathrm{~h}$ after delivery. During the $\mathrm{HI}$ insult, the injured group developed acidosis, hypoxia, hypercapnia, lactic acidosis, and tachycardia (relative to the control group), without hypotension. The intermittent positive pressure ventilation transiently improved gas exchange and cardiovascular parameters. After $\mathrm{HI}$ injury and during ventilatory support, there continued to be an increased $\mathrm{RCBF}$ in inner regions among the $\mathrm{HI}$ group, but no significant differences were detected in cortical flow compared to the control group. Also, the magnitude of the increase in TUNEL positive cells (apoptosis) and antioxidant enzymes, and decrease of ATP reserves was significantly greater in the brain regions where the RCBF was not higher. In conclusion, our findings identify early metabolic, histological, and hemodynamic changes involved in brain damage in premature asphyxiated lambs. Such changes have been described in human neonates, so our model could be useful to test the safety and the effectiveness of different neuroprotective or ventilation strategies applied in the first hours after fetal $\mathrm{HI}$ injury.

Keywords: hypoxic-ischemic injury, total and regional cerebral blood flow, apoptosis, premature fetal lamb, perinatal life

\section{INTRODUCTION}

Perinatal asphyxia is produced by a reduction in blood flow (ischemia) or oxygenation (hypoxia) and most likely for both reasons (Vannucci, 1990; Johnston et al., 2001). Between two and four of every 1000 full-term live births suffer asphyxia during prenatal or intrapartum periods, representing up to $90 \%$ of neonatal hypoxic-ischemic (HI) lesions, and over $20 \%$ of $\mathrm{HI}$ newborns have respiratory failure, and need ventilatory support (Vannucci and Perlman, 1997). Although technological advances have greatly improved neonatal management, no reduction in the prevalence of cerebral palsy or neurological dysfunction has been consistently confirmed.

Many experimental models have been used to study hemodynamic and neurological changes in preterm or near-term fetal lambs in which an $\mathrm{HI}$ event is produced by means of internal iliac artery occlusion, reduction of maternal inspired $\mathrm{O}_{2}$, or umbilical cord occlusion (Gunn et al., 1992; Penning et al., 1994; Ikeda et al., 1998a). These studies did not, however, investigate postnatal resuscitation treatments and evaluation of brain damage during the neonatal period (postpartum) as fetuses continued to be on placental respiration. Only a few studies have been performed to assess resuscitation techniques used on lambs, and these were carried out during the final gestational period (140-143 days), by which time lung maturity is complete (Richardson et al., 1989; Smolich et al., 1992). Specifically, other than those to assess resuscitation techniques focused on immature lungs, no studies seem to have been published on brain damage during preterm life.

A possible explanation for brain damage is the free radical theory and the magnitude and duration of ATP depletion, which depends on irreducible ATP consumption, metabolic reserves, and physiological readjustment. In premature and full-term animals, neuronal necrosis and apoptosis suggest that such processes take place faster than in adults Horn and Schlote, 1992; Vannucci and Perlman, 1997). Thus any intervention to reduce neuronal injury will be most effective in the 2- to 6-h following birth asphyxia (Nagdyman et al., 2001). Therefore, it is important to discover 
reliable early indicators of brain damage (Nagdyman et al., 2001), and to employ early interventions in the first hours after birth.

This study aims to: (1) assess changes in total and regional cerebral blood flow (RCBF); (2) describe changes in cerebral brain metabolism; (3) analyze the activity of antioxidant enzymes; and (4) evaluate histological changes in the brain during the first $3 \mathrm{~h}$ of postnatal life following induction of severe fetal asphyxia.

\section{MATERIALS AND METHODS ANIMALS AND SURGICAL PREPARATION}

Eighteen preterm lambs were delivered by cesarean section at $133 \pm 1$ days (term: 145 days). We used fetal lambs at $88 \%$ of gestation, which have immature lungs (Gastiasoro et al., 2006) while the degree of maturity of the brain is considered to be similar to that of the full-term newborn infant (Raju, 1992). The experimental protocol met all regulations for animal research (EU 86/609 and $\mathrm{RD} 1201 / 2005)$. The ewes were sedated with xylazine $\left(1 \mathrm{mg} \mathrm{kg}^{-1}\right)$ and ketamine hydrochloride $\left(5 \mathrm{mg} \mathrm{kg}^{-1}\right)$, and anesthetized with a continuous infusion of propofol $\left(10 \mathrm{mg} \mathrm{kg}^{-1} \mathrm{~h}\right.$; Gastiasoro et al., 2006). Ewes were intubated and mechanical ventilation was used to maintain normoxia and normocapnia. After laparotomy and hysterotomy, the fetal head was exteriorized and an endotracheal tube ( $4 \mathrm{~mm}$ i.d.) was inserted. Fetal catheters were placed in the right jugular vein, one in the direction of the heart to maintain the fluid balance and anesthesia, and the other in the direction of the brain to collect jugular venous blood. In addition, a 20-gage intravenous catheter was inserted in the superior sagittal sinus for collection of cerebral venous blood, while another catheter was placed in the brachiocephalic trunk (via the left axillary artery) to inject colored microspheres and to obtain an arterial blood sample for blood gas analysis (Gem Premier 4000, Instrumentation-Laboratory, Lexington, MA, USA: $P_{\mathrm{aO}_{2}}, P_{\mathrm{aCO}}, \mathrm{pH}$, base excess, $\mathrm{O}_{2}$ saturation, and acid lactic). This catheter was also used to measure mean arterial blood pressure (MABP) and heart rate (HR). The left carotid artery was isolated and a non-invasive ultrasonic perivascular flow probe (MA3PS, Transonics, Ithaca, FL, USA) was placed to continuously measure carotid blood flow $\left(\mathrm{C}_{\text {arotid }} \mathrm{BF}\right)$.

In this study ketamina was infused for anesthetic purposes to fetal lamb. The use of an anesthetic agent may be controversial due to its effect on fetal cerebral blood flow and its possible neuroprotective effect, but is crucial in ethical animal research. Ketamine is a non-competitive agonist of NMDA receptor; therefore, as a NMDA antagonist it might reduce excitotoxic brain damage (Spandau et al., 1999). This protective effect, however, has been demonstrated to be dose-dependent. Thus, ketamine only reduces post-ischemic brain damage in newborn rats at doses greater than $20 \mathrm{mg} \mathrm{kg}^{-1}$, which is the minimum dose reported for ketamine to block NMDA receptors when administered in vivo (Spandau et al., 1999). In our experiments, however, we infused ketamine at only $4 \mathrm{mg} \mathrm{kg}^{-1} \mathrm{~h}$ for $3 \mathrm{~h}$ (total dose $12 \mathrm{mg} \mathrm{kg}^{-1}$ ), a dose below that reported for ketamine induced neuroprotection.

\section{HYPOXIC-ISCHEMIC INJURY}

The HI injury was induced by partial occlusion of umbilical blood flow for 60 min using a vascular occluder (OC20HD, Harvard Apparatus, MA, USA). The end point was defined by an arterial $\mathrm{pH}<7.1$ and a base excess $<-12 \mathrm{mEq} \mathrm{L}^{-1}$ (Ikeda et al., 1998a).
Following the period of occlusion, the umbilical cord was cut. Animals were weighed and placed in an open incubator. Anesthesia and paralysis was maintained by continuous infusion of hydrochloride ketamine $\left(4 \mathrm{mg} \mathrm{kg}^{-1} \mathrm{~h}\right)$ in $5 \%$ dextrose and pancuronium bromide ( $1 \mathrm{mg} \mathrm{kg}^{-1} \mathrm{~h}$; Gastiasoro et al., 2006). Their core temperature was kept between 38 and $39^{\circ} \mathrm{C}$.

\section{VENTILATOR SUPPORT}

Each lamb, placed in an open incubator, was connected to a timecycled pressure-limited neonatal ventilator with the following settings: respiratory frequency $\left(f_{\mathrm{R}}\right) 60$ breath $\mathrm{min}^{-1}$; PIP: $30 \mathrm{cmH}_{2} \mathrm{O}$; PEEP: $5 \mathrm{cmH}_{2} \mathrm{O}$; I:E 1:2; $F_{\mathrm{I}, \mathrm{O}_{2}}: 1.0$, and flow: $10 \mathrm{~L} \mathrm{~min}^{-1}$. Throughout the period each animal was on a ventilator, the settings (PIP and $f_{\mathrm{R}}$ ) were adjusted in an attempt to normalize $P_{\mathrm{aCO}}$ values between 30 and $50 \mathrm{mmHg}$. PIPs higher than $40 \mathrm{cmH}_{2} \mathrm{O}$ were not used to avoid pneumothoraces.

To assess the effectiveness of mechanical ventilation in each animal (Gastiasoro et al., 2006): oxygenation index $\left(\mathrm{OI}=F_{\mathrm{I}, \mathrm{O}_{2}} \times\right.$ MAP $\left.\times 100 / P_{\mathrm{aO}_{2}}\right)$, and ventilation efficiency index (VEI $=$ $\left.3800 /\left[(\mathrm{PIP}-\mathrm{PEEP}) \times f_{\mathrm{R}} \times P_{\mathrm{aCO}_{2}}\right]\right)$ were calculated.

\section{STUDY DESIGN}

Lambs were randomly assigned to either the control group: no induction of fetal $\mathrm{HI}$ injury and following cutting of the umbilical cord, lambs were managed on intermittent positive pressure ventilation for $3 \mathrm{~h}(n=6)$; or the HI group: fetal HI injury induced as described above, and then management like the controls, on intermittent positive pressure ventilation for $3 \mathrm{~h}(n=6)$.

\section{MEASUREMENTS}

Blood samples were obtained from the right jugular vein (brain direction) and from the superior sagittal sinus to compare the $P_{\mathrm{O}_{2}}$ measurements from the two locations. Also, arterial blood samples were obtained from the brachiocephalic trunk to measure blood gases, lactic acid, and cardiac troponin I (cTnI; AQT90, Radiometer, Copenhagen, Denmark).

Cerebral arterial (venous) oxygen content $\left(C_{\mathrm{a}(\mathrm{v}) \mathrm{O}_{2}}\right)$, oxygen delivery (OD), and cerebral metabolic rate of oxygen $\left(\mathrm{CMR}_{\mathrm{O}_{2}}\right)$ were calculated as follows (Gleason et al., 1989):

$$
\begin{aligned}
\mathrm{C}_{\mathrm{a}(\mathrm{v}) \mathrm{O}_{2}} & =\left(\mathrm{S}_{\mathrm{a}(\mathrm{v}) \mathrm{O}_{2}} \times \mathrm{Hb} \times 1.39 / 100\right)+\left(P_{\mathrm{a}(\mathrm{v}) \mathrm{O}_{2}} \times 0.003\right) \\
\mathrm{OD} & =\mathrm{C}_{\mathrm{aO}} \times \mathrm{CBF} ; \text { and } \mathrm{CMR}_{\mathrm{O}_{2}}=\left(\mathrm{C}_{\mathrm{aO}} \mathrm{O}_{2}-\mathrm{C}_{\mathrm{vO}_{2}}\right) \times \mathrm{CBF} .
\end{aligned}
$$

Core temperature, $\mathrm{MABP}, \mathrm{HR}$, and $\mathrm{C}_{\text {arotid }} \mathrm{BF}$ were continuously monitored. Data were collected during fetal life at baseline (B) and at the end of $\mathrm{HI}$ injury (HI), and during neonatal life immediately following connection to the ventilator $(\mathrm{V})$ and subsequently every 30 min thereafter until the end of experiment. Upon completion of the study, all animals sustained with a perfusion of ketamine and pancuronium bromide, were sacrificed with an overdose of potassium chloride $\left(150 \mathrm{mg} \mathrm{kg}^{-1}\right)$.

\section{CEREBRAL BLOOD FLOW}

As previously reported (Van Bel et al., 1994, 2006), changes in the $\mathrm{C}_{\text {arotid }} \mathrm{BF}$ measurement, assessed using the transit time technique with ultrasonic flow transducers, were used to indicate changes in cerebral blood flow (CBF). 


\section{TISSUE PREPARATION}

At the end of the experiment, the fetal brains were removed. For each specimen, half the brain was fixed ( $4 \%$ formalin) and divided into: cortical regions, inner regions (striatum, thalamus, and hippocampus), cerebellum, and brainstem to determine RCBF and to perform histological studies; the other half of the brain was immediately placed into dry ice and stored at $-80^{\circ} \mathrm{C}$ until used for biochemical assays. The interval between fetal death and initial processing of the brain was no more than 10 min (Ikeda et al., 2000).

\section{REGIONAL CEREBRAL BLOOD FLOW}

Regional cerebral blood flow was determined using four different colors of microspheres $\left(15 \mu \mathrm{m}\right.$, Dye Track ${ }^{\circledR}$, Triton Technology Inc, San Diego, USA). These were injected within $30-45 \mathrm{~s}$ at B, $\mathrm{HI}$, and 60 and $180 \mathrm{~min}$ later. Each brain piece was weighed and submitted to chemical degradation with alkali in a shaking bath. The disaggregated samples were filtered $(10 \mu \mathrm{m})$ to recover the colored microspheres. Filters were dried, and dimethylformamide was added to extract dye from the microspheres. The optical density was measured using a spectrophotometer at four different wavelengths to determine the number of microspheres per sample. Having obtained the number of microspheres per sample (tissue microspheres), we calculated the number of microspheres for the entire brain (reference microspheres). To ensure the accuracy of the statistical analysis, all tissue samples contained at least 400 microspheres. RCBF was calculated as previously described, using CBF as the reference flow (Meadow et al., 1999):

Tissue flow $=($ Tissue microspheres $\times$ Reference flow $) /$ Reference microspheres.

\section{HISTOLOGICAL ANALYSIS}

The histological examinations were carried out by a neuropathologist who was blinded to the study. Different areas of the brains were embedded in paraffin wax to prepare sections for light microscopy and stained for routine histological examination (hematoxylineosin). In addition, DNA fragmentation was examined using the TUNEL method (ApopTag Kit, Intergene, NY, USA). Only cells with clearly apoptotic morphology were noted. The number of apoptotic cells was expressed as number of labeled cells per highpower magnification (HPF), namely those observed using $10 \times$ and $20 \times$ objectives (Falkowski et al., 2002). The objective used was a Plan $20 \times / 0.40 / 0.17$, meaning that these HPFs correspond to an image covering an area of $1 \mathrm{~mm}^{2}$. In all cases, we counted all consecutive images and repeated the procedure in three paraffin sections $(20 \mu \mathrm{m}$ apart). The number of apoptotic cells was expressed as the number of cells $\times 10^{-2} \mathrm{~mm}^{-2}$. Sections of involuting mammary glands were used as positive controls for the TUNEL method.

\section{BIOCHEMICAL ANALYSIS}

Brain samples were rapidly weighed and kept cold by the addition of liquid nitrogen. Samples were homogenized, deproteinized, slowly allowed to thaw, neutralized, and centrifuged. The supernatant was used for ATP measurements, expressed as mmolATP $\mathrm{g}^{-1}$ of tissue (Lamprecht and Trautschold, 1974). To determine antioxidant enzyme activity, brain tissue was weighed, homogenized, centrifuged, and the supernatant removed.
Catalase activity assays were used to measure the reduction of $\mathrm{H}_{2} \mathrm{O}_{2}$ to $\mathrm{H}_{2} \mathrm{O}$ by catalase (Holmes and Masters, 1969). One unit of catalase is defined as the amount of enzyme needed to react with $1 \mu \mathrm{mol}$ of $\mathrm{H}_{2} \mathrm{O}_{2} \mathrm{~min}^{-1}$. Similarly, glutathione-peroxidase (GSH$\mathrm{Px})$ activity assays were employed to measure the reduction of $\mathrm{H}_{2} \mathrm{O}_{2}$ to $\mathrm{H}_{2} \mathrm{O}$ by GSH-Px (Paglia and Valentine, 1967). One unit of GSH-Px is defined as the amount of NADPH oxidation $\cdot \mathrm{min}^{-1}$. Further, we performed superoxide-dismutase (SOD) assays using a kit purchased from Cayman Chemical (Ann Arbor, MI, USA; Cat no.706002). One unit of SOD is defined as the amount of enzyme needed to exhibit $50 \%$ dismutation of the superoxide radical.

Lastly, DNA determination was performed using a fluorometric method that relies on the intercalation of a fluorescent dye (Hoechst 33342) into intact double stranded DNA (Labarca,

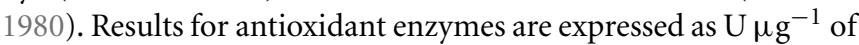
DNA.

\section{DATA ANALYSIS}

Data are expressed as mean $\pm \mathrm{SD}$. Results were assessed using the Levene test to confirm the homogeneity of variance between the different treatments and the Kolmogorov-Smirnoff test for normality (StatView SE Graphics; Abacus Concepts, Orlando, FL, USA). One-way analysis of variance (ANOVA) was performed to assess differences in gas exchange, $\mathrm{OD}, \mathrm{CMR}_{\mathrm{O}_{2}}, \mathrm{C}_{\mathrm{aO}}$, hemodynamic parameters, ventilation indexes, RCBF, antioxidant enzymes, and apoptotic count as a function of group. Comparison of parameters (gas exchange, $\mathrm{OD}, \mathrm{CMR}_{\mathrm{O}_{2}}, \mathrm{C}_{\mathrm{aO}}$, hemodynamic parameters, ventilation indices, and RCBF) were performed by two-way ANOVA for repeated measures as a function of group and time with and without the Bonferroni-Dunn correction. Pearson correlation and linear regression analysis were performed to compare $P_{\mathrm{O}_{2}}$ of the jugular vein and the superior sagittal sinus. A $p$-value of 0.05 was accepted as significant.

\section{RESULTS}

Briefly, all ewes were found to have sufficient and stable gas exchange and cardiovascular parameters ( $\mathrm{pH}: 7.42 \pm 0.06 ; \mathrm{PCO}_{2}$ : $40 \pm 9 \mathrm{mmHg} ; P_{\mathrm{aO}_{2}}: 130 \pm 32 \mathrm{mmHg}$ MABP: $70 \pm 10 \mathrm{mmHg}$ ) throughout the study.

\section{GAS EXCHANGE, OD, AND CMR $\mathbf{O}_{2}$}

All lambs were alive at the completion of the experiments. At baseline, they all had an adequate acid-base balance and gas exchange in the placenta (Table 1) with normal levels of lactic acid $\left(4 \pm 1 \mathrm{mmol} \mathrm{L}^{-1}\right)$ and $\mathrm{cTnI}\left(0.02 \pm 0.01 \mu \mathrm{g} \mathrm{L}^{-1}\right)$.

Following HI injury, HI lambs displayed arterial acidosis, hypercapnia, and a significant decrease in $P_{\mathrm{aO}_{2}}, \mathrm{C}_{\mathrm{aO}}$, and base excess $\left(-14 \pm 3\right.$ vs. $\left.1 \pm 3 \mathrm{mEq} \mathrm{L}^{-1}\right)$ with a significant increase in lactic acid $\left(12 \pm 3\right.$ vs. $\left.4 \pm 1 \mathrm{mmol} \mathrm{L}^{-1}\right)$ and $\mathrm{cTnI}(0.25 \pm 0.13$ vs. $\left.0.02 \pm 0.01 \mu \mathrm{g} \mathrm{L}^{-1}\right)$ levels compared to the control group (Table 1). During postnatal life with mechanical ventilatory support, control groups demonstrated better gas exchange $(\mathrm{pH}$ and $\left.P_{\mathrm{aCO}_{2}}\right)$ with lower mean oxygenation level by the end of experiments (Table 1), while higher lactic acid (10 \pm 2 vs. $\left.4 \pm 1 \mathrm{mmol} \mathrm{L}^{-1}\right)$ and $\mathrm{cTnI}\left(0.56 \pm 0.13\right.$ vs. $\left.0.13 \pm 0.08 \mu \mathrm{g} \cdot \mathrm{L}^{-1}\right)$ concentrations, with lower $\mathrm{C}_{\mathrm{a}} \mathrm{O}_{2}, \mathrm{OD}$, and $\mathrm{CMR}_{\mathrm{O}_{2}}$, were noted in the HI group (Table $\mathbf{1}$ ). 


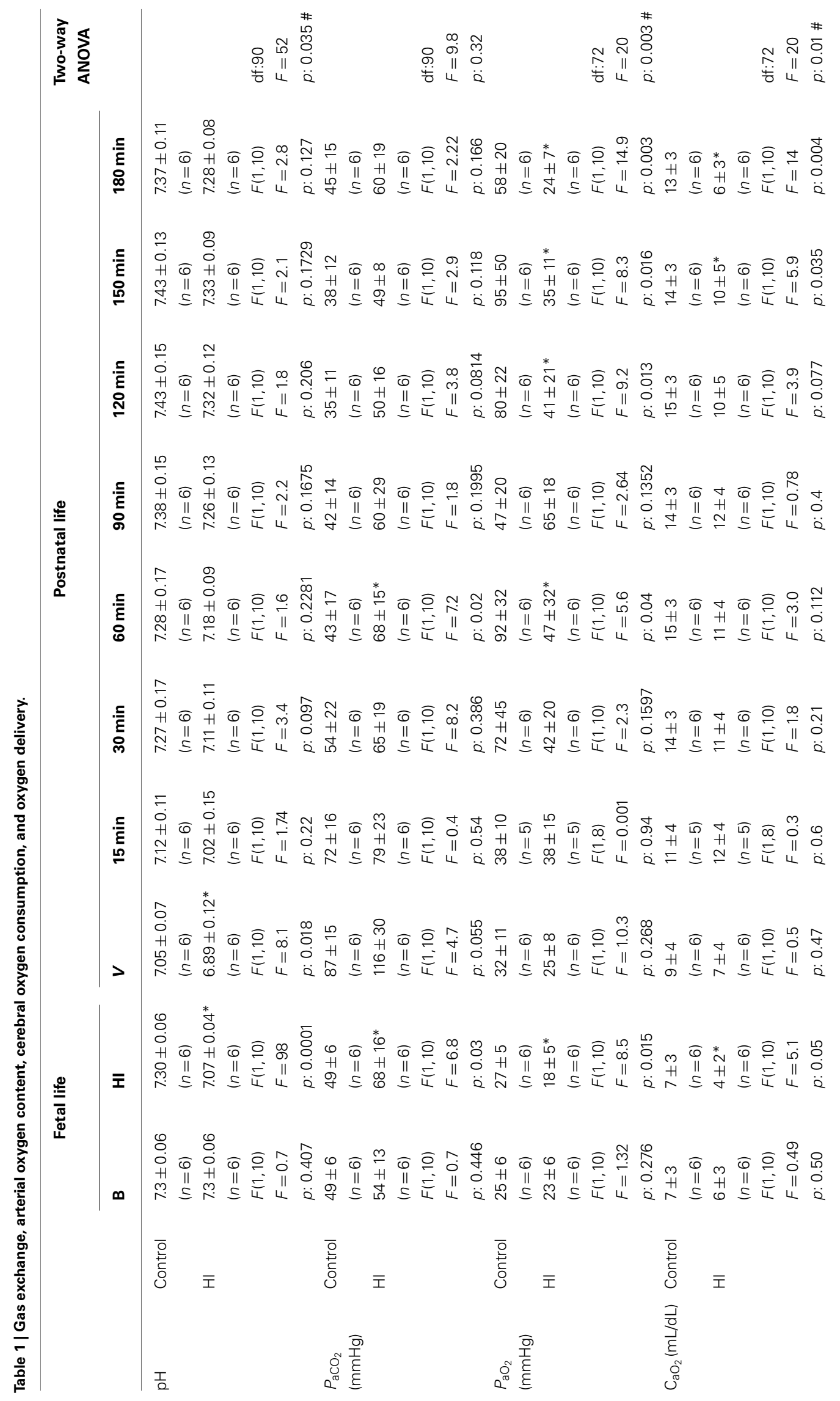




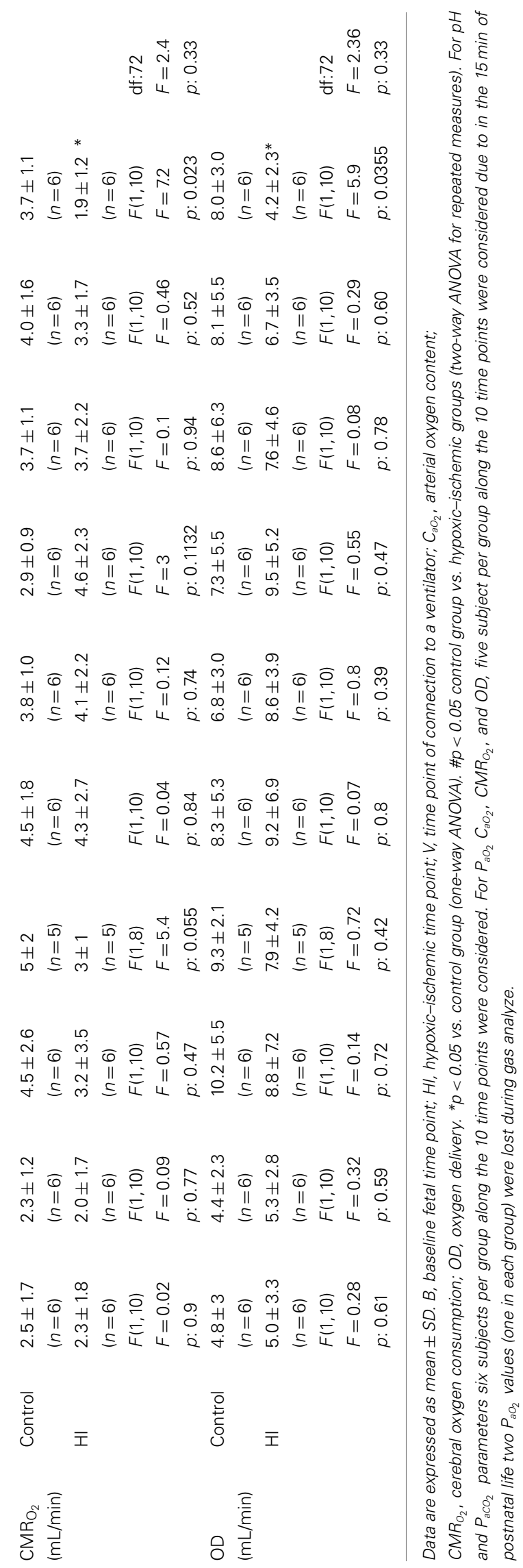


Differences in oxygenation were independent of the ventilation strategy. Although, both groups were ventilated with similar mean airway pressure (data not shown) and at a constant $F_{\mathrm{I}_{1} \mathrm{O}_{2}}$ of 1.0 throughout the study, OI was higher in the HI group than among the controls from 30 min onward (Table 2). On the other hand, there were no statistically significant differences in VEI between groups (Table 2).

Differences demonstrated by two-way ANOVA with Bonferroni correction in $\mathrm{pH}, \mathrm{P}_{\mathrm{aO}}, \mathrm{C}_{\mathrm{aO}}$, and $\mathrm{OI}$ parameters, were also detected as trends consistent with the overall effects observed in $\mathrm{pH}, \mathrm{P}_{\mathrm{aCO}_{2}}, \mathrm{P}_{\mathrm{aO}_{2}}, \mathrm{C}_{\mathrm{aO}}$, and $\mathrm{IO}$ at several time intervals, and in $\mathrm{CMR}_{\mathrm{O}_{2}}$ and $\mathrm{OD}$ at specific time points, using a less conservative strategy without Bonferroni correction.

\section{VENOUS OXYGEN CORRELATION}

A close relationship was found (Pearson correlation coefficient $\left.r=0.92 ; R^{2}=0.85 ; p<0.001\right)$ between jugular vein $P_{\mathrm{vO}_{2}}$ and superior sagittal sinus $P_{\mathrm{vO}_{2}}(n=36): P_{\mathrm{vO}_{2}}$ sagittal sinus $=0.55 *$ $P_{\mathrm{vO}_{2}}$ jugular vein +4.87 was used to calculate $\mathrm{C}_{\mathrm{vO}_{2}}$ andCMR $\mathrm{O}_{2}$.

\section{CARDIOVASCULAR PARAMETERS}

No significant differences between groups were detected in MABP during the experiment (Table 2). During partial occlusion of the umbilical cord and initial ventilation, a significant increase in HR developed in HI animals (Table 2) compared to controls. During ventilation, the HR first decreased in the HI group to reach basal values (min. 60), and later increased again reaching post HI values by the end of experiment.

Differences demonstrated by two-way ANOVA with Bonferroni correction in HR and CBF parameters, were also detected as trends consistent with the overall effects observed in at several time intervals, and in MABP at $60 \mathrm{~min}$, using a less conservative strategy without Bonferroni correction.

\section{REGIONAL AND CEREBRAL BLOOD FLOW}

A marked increase in CBF was observed after partial occlusion of the umbilical cord in HI animals (Table 2). During ventilatory support, CBF maintained constant for the whole time in both groups. RCBF data are summarized in Figure 1. In the control group, RCBF did not exhibit significant changes during the fetal or neonatal period compared to baseline. By contrast, in the $\mathrm{HI}$ group, at HI, there was an increase in RCBF in the inner zones and in the cerebellum-brainstem, though no significant changes were observed in cortical RCBF. During ventilatory support, the RCBF in inner zones remained higher in the HI group, but there were no significant differences between groups in cortical and cerebellumbrainstem flows. When inner zones were studied separately, it was found that the RCBF only increased significantly in the thalamus (Figures 1 and 3B).

\section{HISTOLOGICAL ANALYSIS}

Samples exhibited good histological preservation (8-10 on the scale of van Reempts). Mild perivascular and interstitial edema was observed, the most affected zones being: the mesencephalon, brainstem, deep cerebellar nuclei, and cerebral cortex. Neurons showing coagulative changes were observed in the basal ganglia, mesencephalon, brainstem, and deep cerebellar nuclei (Figure 2A).
The quantification of cell death using the TUNEL method revealed that only $3 \mathrm{~h}$ after HI injury the number of TUNEL positive cells was higher in the HI group than the control group, and that these were mainly located in the cerebral cortex, cerebellum, and brainstem, but also in the striatum (Figure 2B). The increase in TUNEL positive cells was significantly greater in the brain regions where the RCBF values had not increased (Figure 3B).

\section{BIOCHEMICAL ANALYSIS}

The HI group displays a significant loss of energy reserves (ATP) in the brain regions where the RCBF values were not higher than in the control group, showing a similar pattern to TUNEL positive cells (Figure 3C). Figure 4 shows the antioxidant enzyme activity in the different brain regions. SOD activity was higher in asphyxiated animals, a finding that reached statistical significance in the cortical regions and striatum (Figure 4A). Catalase and GSH-Px activity did not differ significantly between the two groups, except that catalase activity in the cortical regions was significantly higher in $\mathrm{HI}$ injured group (Figures 4B,C).

\section{DISCUSSION}

The transition from fetal to neonatal life is a time of rapid physiological changes that may be aggravated if episodes of asphyxia occur during fetal life. In the perinatal period, a few studies have been performed to assess techniques to support postnatal recovery in fetal lambs at 140-143 days of gestation (when maturity of the lungs is complete; Richardson et al., 1989; Smolich et al., 1992). However, as far as we are aware no studies previous studies, performed to evaluate the management of postnatal recovery focusing on immature lungs, have assessed brain damage during early postnatal life.

The fetal sheep model was chosen because it is a well-established model for the evaluation of the cerebral circulation and metabolism (Gleason et al., 1989; Richardson et al., 1996). Several methods have been used to induce brain damage: occlusion of the common/internal iliac artery (Gunn et al., 1992), reduction of maternal inspired $\mathrm{O}_{2}$ fraction (Penning et al., 1994), and umbilical cord occlusion (Ikeda et al., 1998a). However, in those studies, the brain damage during neonatal life (postpartum) was not studied, the fetus being maintained on placental respiration. The premature fetal sheep model has been very useful for studying lung immaturity related to prematurity (Björklung et al., 2001; Gastiasoro et al., 2006), as lung maturation is not complete up to 135 gestational days (Gastiasoro et al., 2006). In our study, during the period of neonatal ventilation, the management, and effectiveness of mechanical ventilation, based on mean airway pressure and VEI was similar in the two groups. In addition, following the start of mechanical ventilation, all animals had severe respiratory insufficiency, manifested by an OI greater than 15 , which was getting worse with time, so it was necessary to increase $F_{\mathrm{I}, \mathrm{O}_{2}}$ to 1.0 . However, in the HI group, the OI was even higher than in the control group, and this can be attributed to the HI event.

Newborn encephalopathy is often accompanied by dysfunction of other end organs (Martin-Arcel et al., 1995). Clinical research has suggested that infants at the highest risk of $\mathrm{HI}$ brain damage exhibit progressive fetal HR abnormalities shortly before birth, $\mathrm{pH}<7.1$ and arterial lactate concentration $>9 \mathrm{mmol} / \mathrm{L}$ and 


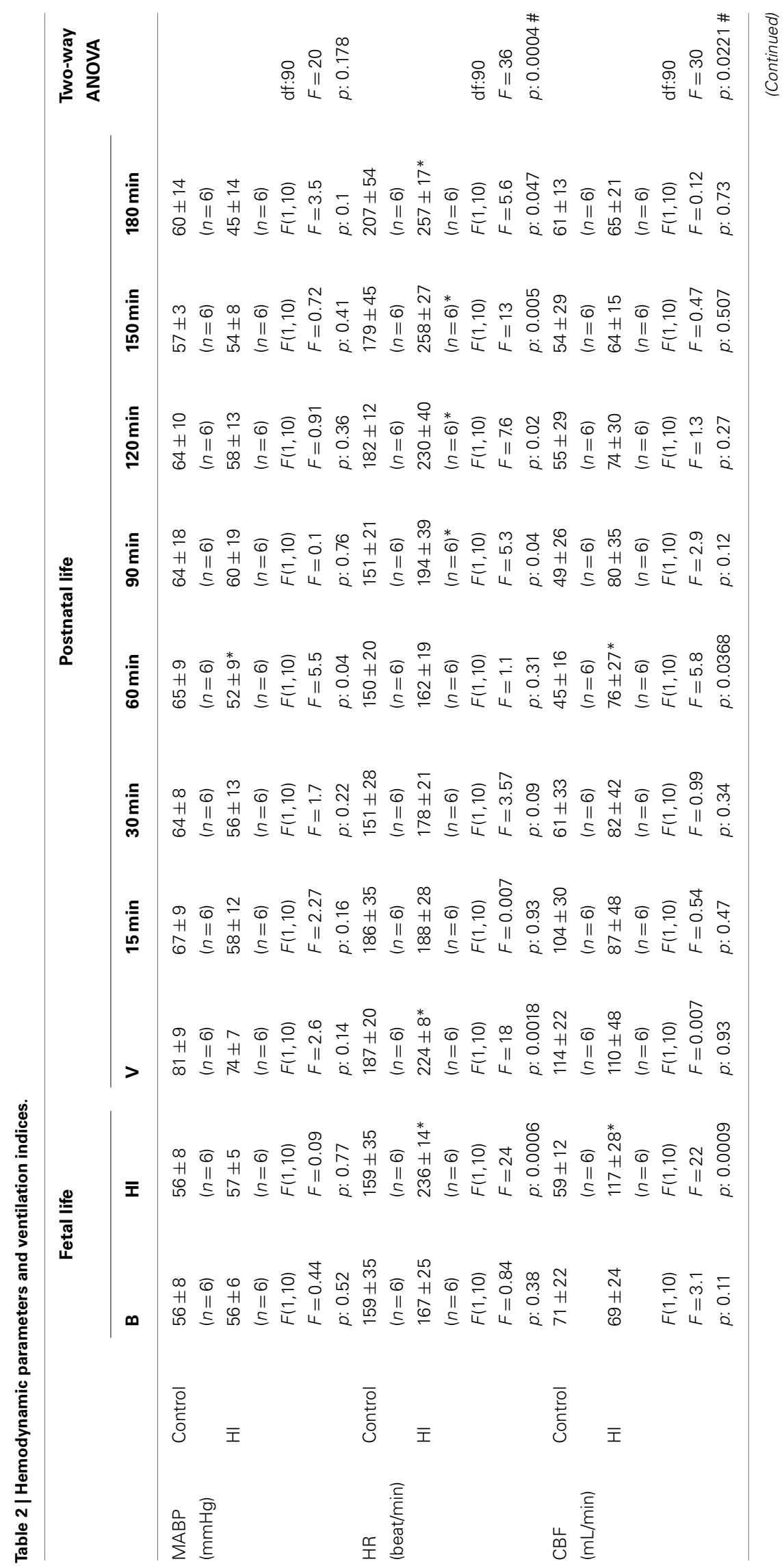




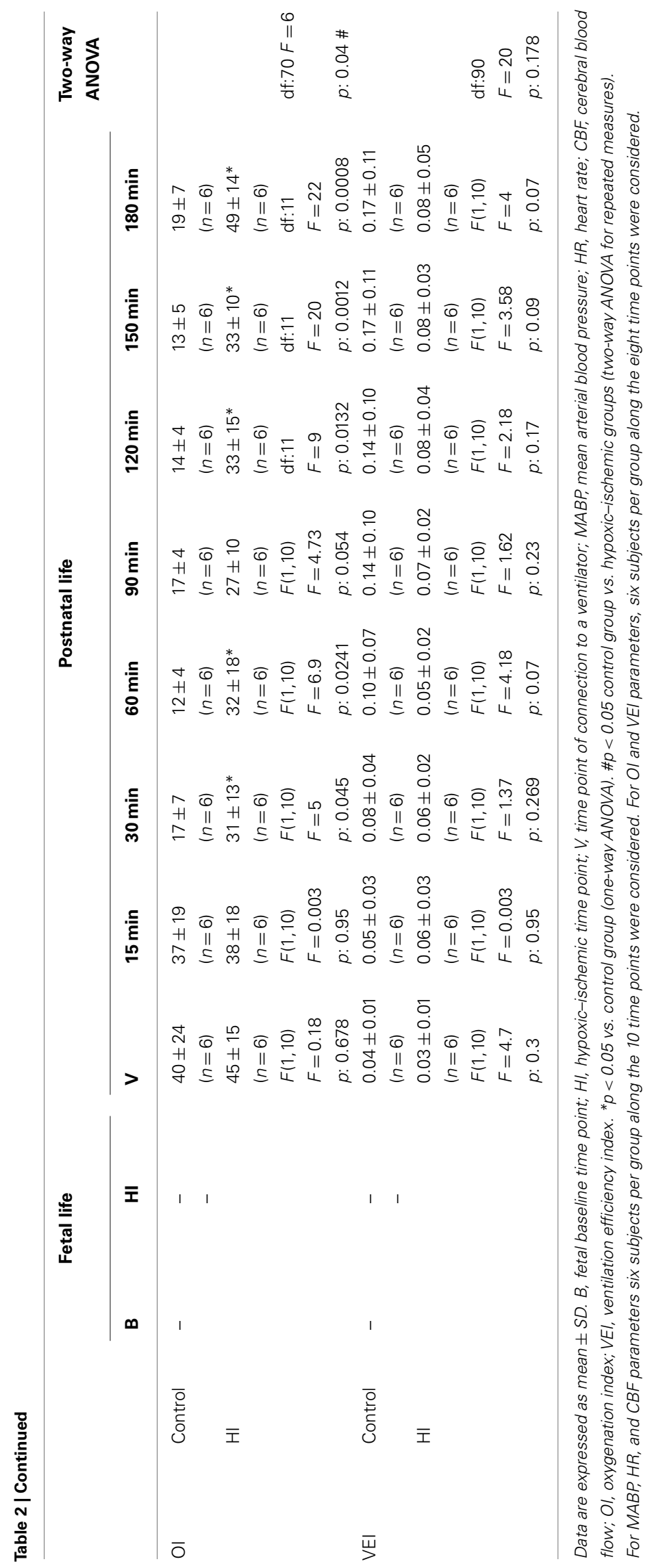



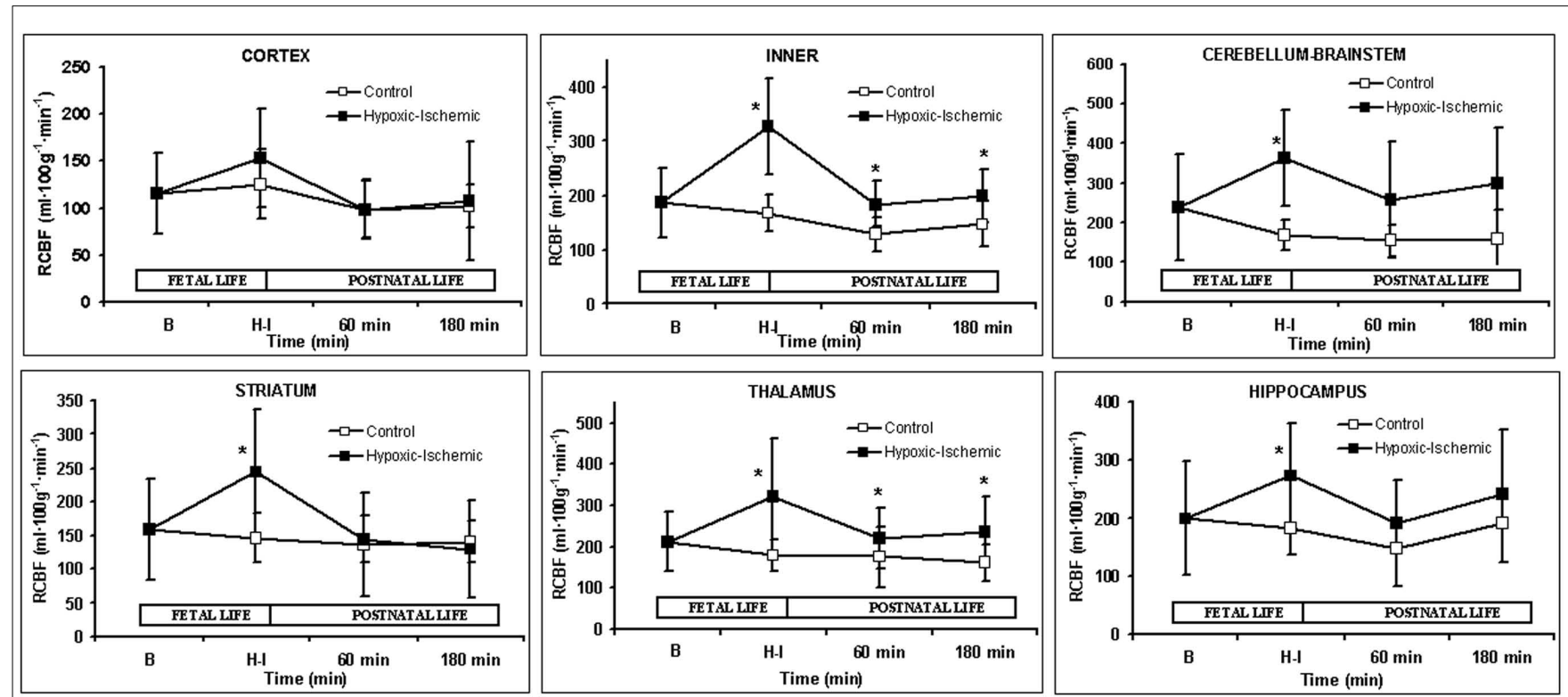

FIGURE 1 | Regional cerebral blood flow ( $\mathbf{m L ~} \mathbf{1 0 0 \mathbf { g } ^ { - 1 } \mathbf { ~ } \mathbf { m i n }}{ }^{-1}$ ). Data are expressed as mean \pm SD. Mean values for both control (open square) and hypoxic-ischemic (close square) groups are represented as function of time; Baseline (B), Hypoxic-Ischemic (HI), 60 and 180 min points. ${ }^{*} p<0.05$ vs. control group (one-factor ANOVA).

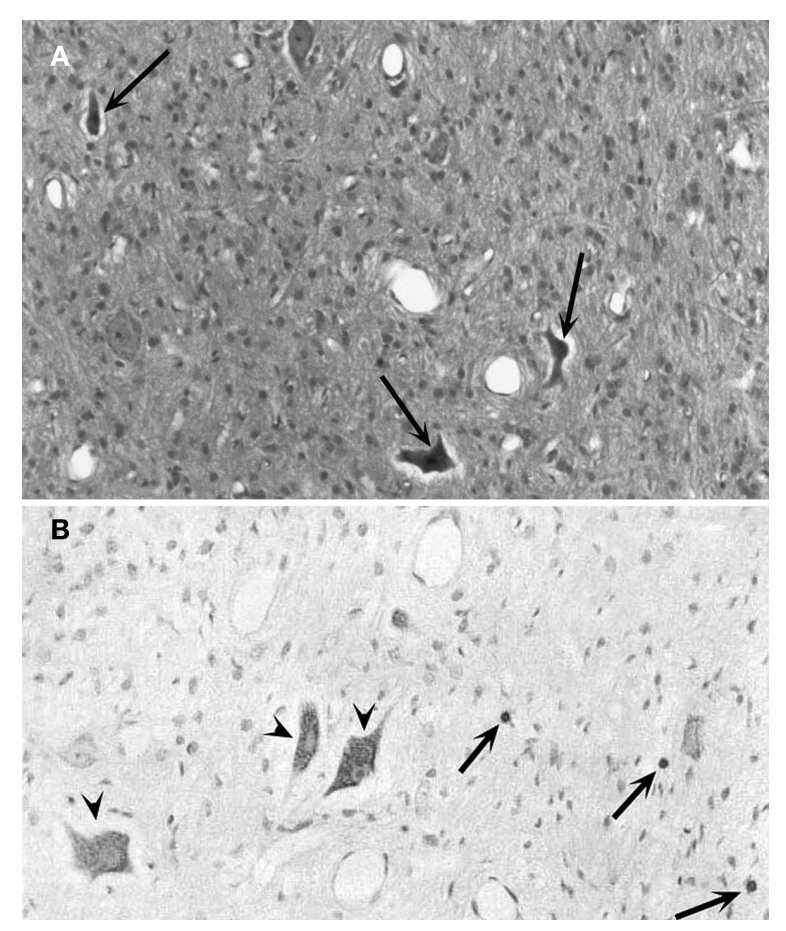

FIGURE 2 | Histological analysis. (A) View of the brain stem $3 \mathrm{~h}$ after hypoxic-ischemic injury. Presence of large eosinophilic neurons (arrows) Hematoxylin-eosin stain. Original magnification $\times 200$. (B) Cells with apoptotic morphology figures (arrow) in the basal ganglia of the hypoxic-ischemic group. On the left (arrowhead), damaged neurons with a negative stain for TUNEL can also be observed. TUNEL counterstained with methyl green. Original magnification $\times 400$. require major resuscitation in the delivery room, including cardiac massage and intubation (Low et al., 1994; da Silva et al., 2000). In our model, the HI injury was induced by partial umbilical cord occlusion for $1 \mathrm{~h}$ resulting in severe acidosis, with an increase in levels of lactic acid, as well as severe hypercapnia, hypoxia, and a decrease in $\mathrm{C}_{\mathrm{aO}_{2}}$. An increase in the troponin level, even a slight one, usually means there has been some damage to the heart. Healthy-termed newborns have a higher upper reference limit for $\mathrm{cTnT}(50 \pm 60 \mu \mathrm{g} / \mathrm{L})$ compared to adults being less than $10 \mu \mathrm{g} / \mathrm{L}$ (Badera et al., 2006). Cardiovascular compromise as impaired myocardial contractility and low cardiac output is common in sick term and preterm infants with perinatal asphyxia, this reduced cardiovascular reserve may present with hypotension. In contrast with previous observations, the $\mathrm{HI}$ injury did not produce changes in MABP (Keumen et al., 1997; Ikeda et al., 1998a) but we observed an increased HR that might have maintained cardiac output. Tachycardia with no change in MABP is associated with acute hypoxemia due to the stimulation of the sympathetic system (Serwer, 1992). In this point (immediately after HI injury) a significant increase of serum cTnI $(0.25 \pm 0.13 \mu \mathrm{g} / \mathrm{mL})$ was not enough to demonstrate heart dysfunction $(>50 \pm 60 \mu \mathrm{g} / \mathrm{L})$. However, after $3 \mathrm{~h}$ of HI injury a decrease of MABP (hypotension) was observed in $\mathrm{HI}$ group associated with a significant increase of serum cTnI $(0.56 \pm 60 \mu \mathrm{g} / \mathrm{L})$, suggesting the presence of heart disorder.

There is an inverse correlation between the changes in $\mathrm{C}_{\mathrm{aO}_{2}}$ and CBF (Jones et al., 1981) in order to maintain cerebral oxygenation and glucose supply. In line with this relationship, no significant differences were found in cerebral OD between our groups, the increase in $\mathrm{CBF}$ compensating for the fall in $\mathrm{C}_{\mathrm{aO}}$. This correlation is maintained during $\mathrm{HI}$ event while hemodynamic parameters are stable. However, in the later period following asphyxia, cerebral 

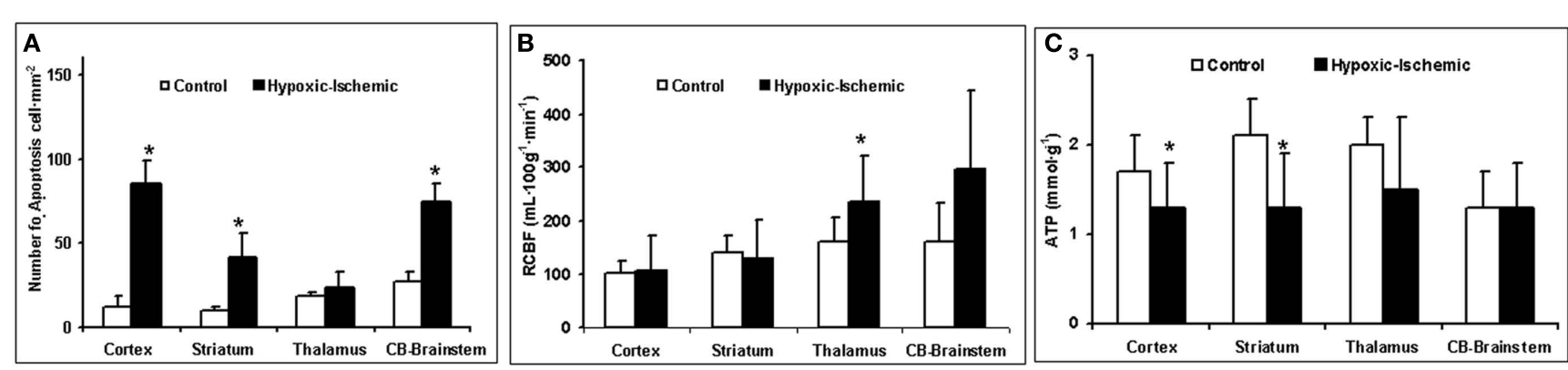

FIGURE 3 | (A) Number of apoptotic cells $\cdot \mathrm{mm}^{-2}$. (B) Regional cerebral blood flow $\left(\mathrm{mL} 100 \mathrm{~g}^{-1} \mathrm{~min}^{-1}\right)$. (C) ATP concentration $\left(\mathrm{mmol} \mathrm{g}^{-1}\right)$ as function of brain region and experimental group. Data are expressed as mean $\pm \mathrm{SD}$. ${ }^{*} p<0.05$ vs. control group (one-factor ANOVA).
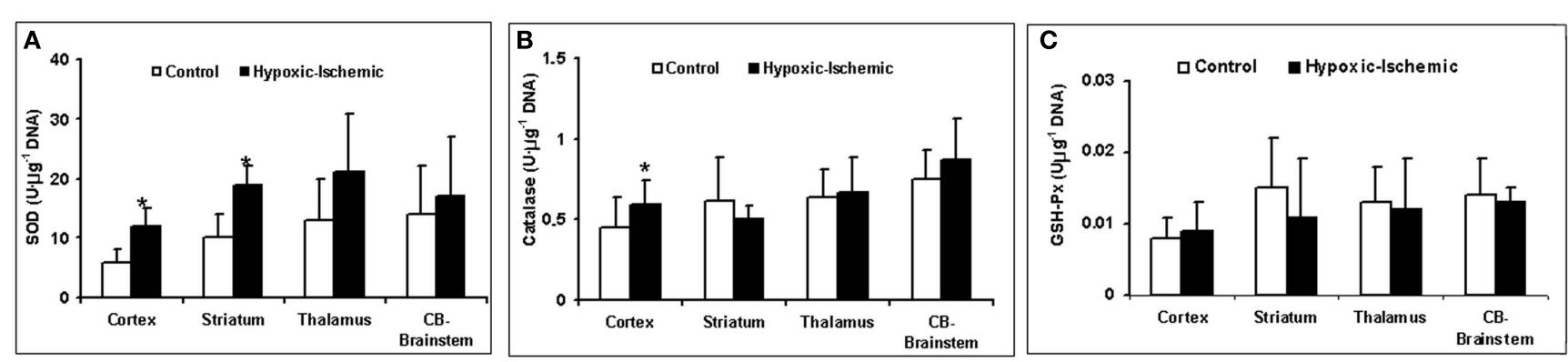

FIGURE 4 | Antioxidant enzymes activity (U $\boldsymbol{\mu g}^{-1}$ of DNA). (A) SOD activity. (B) Catalase activity. (C) GSH-Px activity as function of different brain regions and experimental group. ${ }^{*} p<0.05$ vs. control group (one-factor ANOVA).

$\mathrm{OD}$, and $\mathrm{CMR}_{\mathrm{O}_{2}}$ decreased significantly in the $\mathrm{HI}$ group, and we attribute this to $\mathrm{CBF}$ increases not being sufficient (myocardical dysfunction) to compensate for the continuing fall in $\mathrm{C}_{\mathrm{aO}_{2}}$. For the calculation of $\mathrm{CMR}_{\mathrm{O}_{2}}$ sagittal sinus blood samples cannot be substituted for by jugular vein samples in the pig, but in this lamb model we confirmed that there is a good correlation, as previously described (Van Bel et al., 1994, 2006). This finding is very useful because sagittal sinus cannulation is not always possible and/or presents technical problems (decannulation, inadvertent bleeding, tissue hemorrhage, etc.).

Our previous results suggest that there is a relationship between the type of cell death occurring early after $\mathrm{HI}$ injury and its location in the brain (Goñi de Cerio et al., 2007). For perinatal animals and, presumably, human infants, the process of cell destruction is more rapid than for adults (Vannucci and Perlman, 1997), so any therapeutic intervention will be more successful if it is employed soon after assault, between 2 and $6 \mathrm{~h}$ after birth asphyxia (Nagdyman et al., 2001). In our model, the pattern of necrosis is located fundamentally in subcortical regions (Goñi de Cerio et al., 2007). The higher metabolic rate of subcortical nuclei compared to that in cerebral hemispheres explains the preponderance of subcortical damage observed in experimental animal models and human term infants (Reddy et al., 1998; Avery, 2005). Neuronal necrosis in our model occurs swiftly during the HI period and these cells, which die due to HI assaults, cannot be rescued, whereas apoptotic processes can occur hours after HI insult (Goñi de Cerio et al., 2007).
The relationship between differential RCBF distribution, biochemical, and cell death at specific brain locations needs to be clarified. After HI injury and during postnatal life, we observed a sustained increase in cerebral blood flow in an internal area of the brain (thalamus), whereas in cortical regions, the striatum and the cerebellum-brainstem flow was similar to baseline, as previously reported (Johnson et al., 1979). Since partial umbilical cord occlusion produces a continuous decrease in $\mathrm{C}_{\mathrm{aO}}$, those brain areas, even with a non-altered flow but receiving less $\mathrm{C}_{\mathrm{aO}}$, are susceptible to developing brain cell injury. Only areas with an increased cerebral blood flow can partially compensate for low $\mathrm{C}_{\mathrm{aO}_{2}}$ by increases in delivery of $\mathrm{O}_{2}$, glucose, and nutrient. In our study, larger numbers of cells with apoptotic features were located in cortical regions, the striatum and the cerebellum-brainstem, where RCBF values were similar to baseline. In contrast, the zones where the RCBF values (thalamus) remained high over time, the number of apoptotic cells did not increase.

The energy balance in the brain is maintained by the production of ATP, and cellular defense mechanisms are able to compensate for oxidative stress. The depletion of high-energy phosphates has been described as a necessary prerequisite to the initiation of the mechanisms underlying cell dysfunction, over production of oxygen free radicals (Johnston et al., 2001), and cell death in the pathogenesis of HI brain damage (Vannucci, 1990). In our study, as early as $3 \mathrm{~h}$ after $\mathrm{HI}$ injury, we have observed a significant increase in antioxidant enzyme activity and a significant decrease in ATP concentration (Ikeda et al., 1998b; Johnston et al., 2001) in the 
cerebral zones where the RCBF values (cortical regions, striatum) were not increased. In contrast, the zones where the RCBF values (thalamus) remained high over time, the ATP concentration and antioxidant enzyme activity did not show significant alteration compared to non-injured group.

\section{CONCLUSION}

Our model of partial cord occlusion for an hour induced changes in gas exchange, cardiovascular profile and deregulation of the RCBF, which is accompanied by a significant decrease in energy stores and increase in antioxidant enzyme activity, resulting in brain lesions that resemble findings observed in infants suffering from HI injury. The findings of this study could be the key to understanding the critical changes between fetal and postnatal

\section{REFERENCES}

Avery, M. (2005). "Neurological and neuromuscular disordes," in Avery's Neonatology: Pathophysiology and Management of the Newborn, 6th Edn, eds M. MacDonald, M. Seshia, and M. Mullett (Philadelphia, PA: Lippincott Williams \& Wilkins), 1384-1409.

Badera, D., Kugelmana, A., Lanirb, A., Tamirc, A., Mulaa, E., and Riskina, A. (2006). Cardiac troponin I serum concentrations in newborns: a study and review of the literature. Clin. Chim. Acta 371, 61-65.

Björklung, L. J., Ingimarsson, J., Curstedt, T., Larsson, A., Robertson, B., and Werner, O. (2001). Lung recruitment at birth does not improve lung function in inmmature lambs receiving surfactant. Acta Anaesthesiol. Scand. 45, 986-993.

da Silva, S., Hennebert, H., Denis, R., and Wayenberg, J.-L. (2000). Clinical value of a single postnatal lactate measurement after intrapartum asphyxia. Acta Paediatr. 89, 320-323.

Falkowski, A., Hammond, R., Han, V., and Richardson, B. (2002). Apoptosis in the preterm and near term ovine fetal brain and the effect of intermittent umbilical cord occlusion. Brain Res. Dev. Brain. Res. 136, 165-173.

Gastiasoro, E., Alvarez, F. J., ReySantano, M. C., Arnaiz, A., Loureiro, B., and Valls-i-Soler, A. (2006). Acute and sustained effects of lucinactant versus poractant- $\alpha$ ? on pulmonary gas exchange and mechanics in premature lambs with respiratory distress syndrome. Pediatrics 117, 295-303.

Gleason, C. A., Hamm, C., and Jones, M. D. (1989). Cerebral blood flow, oxygenation, and carbohydrate metabolism in immature fetal sheep in utero. Am. J. Physiol. 256, R1264R1268.
Goñi de Cerio, F., Alvarez, A., Caballero, A., Mielgo, V. E., Alvarez, F. J., Rey-Santano, M. C., Gastiasoro, E., Valls-i-Soler, A., Bilbao, J., and Hilario, E. (2007). Early cell death after hypoxic-ischemic injury. Brain Res. 1151, 161-171.

Gunn, A. J., Parer, J. T., Mallard, C. E., Williams, C., and Gluckman, P. D. (1992). Cerebral histologic and electrocorticographic changes after asphyxia in fetal sheep. Pediatr. Res. $31,486-491$.

Holmes, R. S., and Masters, C. J. (1969). On the tissue and subcellular distribthe rat. Biochim. Biophys. Acta 1969, 488-490.

Horn, M., and Schlote, W. (1992). Delayed neuronal death and delayed neuronal recovery in the human brain following globla ischemia. Acta Neuropathol. 85, 79-87.

Ikeda, T., Murata, Y., Quilligan, E. J., Choi, B. H., Parer, J. T., Doi, S., and Park, S.-D. (1998a). Physiologic and histologic changes in near-term fetal lambs exposed to asphyxia by partial umbilical cord occlusion. Am. J. Obstet. Gynecol. 178, 24-32.

Ikeda, T., Murata, Y., Quilligan, E. J., Parer, J. T., Doi, S., and Park, S.D. (1998b). Brain lipid peroxidation and antioxidant levels in fetal lambs 72 hours after asphyxia by partial umbilical cord occlusion. Am. J. Obstet. Gynecol. 178, 474-478.

Ikeda, T., Murata, Y., Quilligan, E. J., Parer, J. T., Murayama, T., and Koono, M. (2000). Histologic and biochemical study of the brain, heart, kidney, and liver in asphyxia caused by occlusion of the umbilical cord in near-term fetal lambs. Am. J. Obstet. Gynecol. 182, 449-457.

Johnson, G. N., Palahniuk, R. J., Tweed, W. A., Jones, M. V., and Wade, J. G. (1979). Regional cerebral blood flow changes during severe fetal asphyxia in the brain of fetal preterm lambs ution of multiple forms of catalase in

life and the adaptive response of asphyxiated neonates. Moreover, the good consistency among regional cerebral metabolism, blood flow, and cell death in our model could be useful to test the safety and the effectiveness of different neuroprotective (cannabinoids, hypothermia, magnesium sulfate, etc.,) and ventilation strategies (liquid ventilation, high frequency, etc.,) when they are applied in the first hours after fetal HI injury.

\section{ACKNOWLEDGMENTS}

Partially supported by grants from Carlos III Health Institute (FIS06/839, FIS07/0733, and RD08/0072: Maternal, Child Health, and Development Network within the framework of the Spanish VI National Plan for R + D + i 2008-2011), and the Basque Government (GV2006111020, GV2007111046, and IT-287-07)

produced by slow partial umbilical cord compression. Am. J. Obstet. Gynecol. 135, 48-52.

Johnston, M. V., Trescher, W. H., Ishida, A., and Nakajima, W. (2001). Neurobiology of hypoxic-ischemic injury in the developing brain. Pediatr. Res. 49, 735-741.

Jones, M. D., Traystman, R. J., Simmons, M. A., and Molteni, R. A. (1981). Effects of changes in arterial $\mathrm{O} 2$ content on cerebral blood flow in the lamb. Am. J. Physiol. 240, H209-H215.

Keumen, H., Blanco, C. E., Van Reempts, J. L. H., and Hasaart, T. H. M. (1997). Absence of neuronal damage after umbilical cord occlusion of 10,15 , and 20 minutes in midgestation fetal sheep. Am. J. Obstet. Gynecol. 176, 515-520.

Labarca, C. (1980). A simple, rapid and sensitive DNA assay procedure. Anal. Biochem. 102, 344-352.

Lamprecht, W., and Trautschold, I. (1974). "Determination with hexokinase and glucose-6-phosphate deshydrogenase, in Methods of Enzymatic Analysis, ed. H. U. Bergmeyer (New York: Academic Press), 2101-2110.

Low, J. A., Panagiotopoulos, C., and Derrick, E. J. (1994). Newborn complications after intrapartum asphyxia with metabolic acidosis in the term fetus. Am. J. Obstet. Gynecol. 170, 1081-1087.

Martin-Arcel, A., Garcia-Alix, A., Gaya, F., Cabañas, F., Burgueros, M., and Quero, J. (1995). Multiple organ involvement in perinatal asphyxia. $J$. Pediatr. 127, 786-793.

Meadow, W., Rudinsky, B., Raju, T., John, E., Fornell, L., and Shankararao, R. (1999). Correlation of flow probe determination of common carotid artery blood flow and internal carotid artery blood flow with microsphere determinations of cerebral blood flow in piglets. Pediatr. Res. 45, 324-330.

Nagdyman, N., Kömen, W., Ko, H.K., Müller, C., and Obladen, M. (2001). Early biochemical indicators of hypoxic-ischemic encephalopathy after birth asphyxia. Pediatr. Res. 49, 502-506.

Paglia, D. E., and Valentine, W. N. (1967). Studies on the quantitative and qualitative characterization of erythrocyte glutathione peroxidase. J. Lab. Clin. Med. 70, 158-169.

Penning, D. H., Grafe, M. R., Hammond, R., Matsuda, Y., Patrick, J. E., and Richardson, B. S. (1994). Neuropathology of the near-term and midgestation ovine fetal brain after sustained in utero hypoxemia. Am. J. Obstet. Gynecol. 170, 1425-1432.

Raju, T. (1992). Some animal models for the study of perinatal asphyxia. Biol. Neonate 62, 202-214.

Reddy, K., Mallard, C. E., Guan, J., Marks, K. A., Bennet, L., Gunning, M. I., Gunn, A. J., Gluckman, P. D., and Williams, C. (1998). Maturational change in the cortical response to hypoperfusion injury in the fetal sheep. Pediatr. Res. 43, 674-682.

Richardson, B. S., Carmichael, L., Homan, J., Johnston, L., and Gagnon, R. (1996). Fetal cerebral, circulatory, and metabolic responses during heart rate decelerations with umbilical cord compression. Am. J. Obstet. Gynecol. 175, 929-936.

Richardson, B. S., Carmichael, L., Homan, J., Tanswell, K., and Webster, A. C. (1989). Regional blood flow change in the lamb during the perinatal period. Am. J. Obstet. Gynecol. 160, 919-925.

Serwer, G. A. (1992). "Postnatal circulatory adjustments," in Fetal and Neonatal Physiology, eds R. A. 
Polin and W. W. Fox (Philadelphia: W.S.Saunders Company), 710-721.

Smolich, J. J., Soust, M., Berger, P. J., and Walker, A. M. (1992). Indirect relation between rises in oxygen consumption and left ventricular output at birth in lambs. Circ. Res. 71, 443-450.

Spandau, E., Karkavelas, G., Oubasi, V., Avgovstides-Savvopoulou, P., Loizidis, T., and Guiba-Tziampiri, O. (1999). Effect of ketamine on hypoxic-ischemic brain damage in newborn rats. Brain Res. 819, $1-7$.

Van Bel, F., Bartelds, B., Teitel, D. F., and Rudolph, A. M. (2006).
Effect of indomethacin on cerebral blood flow and oxygenation in the normal and ventilated fetal lamb. Pediatr. Res. 38, 243-250.

Van Bel, F., Roman, C., Klautz, R. J. M., Teitel, D. F., and Rudolph, A. M. (1994). Relationship between brain flow and carotid arterial flow in the sheep fetus. Pediatr. Res. 35, 329-333.

Vannucci, R. C. (1990). Experimental biology of cerebral hypoxiaischemia: relation to perinatal brain damage. Pediatr. Res. 27, 317-326.

Vannucci, R. C., and Perlman, J. M. (1997). Interventions for perinatal hypoxic-isquemic encephalopathy. Pediatrics 100 1004-1014.

Conflict of Interest Statement: The authors declare that the research was conducted in the absence of any commercial or financial relationships that could be construed as a potential conflict of interest.

Received: 25 January 2011; accepted: 29 August 2011; published online: 20 September 2011.

Citation: Rey-Santano C, Mielgo VE, Gastiasoro E, Murgia X, Lafuente $H$, Ruiz-del-Yerro E, Vallsi-Soler A, Hilario E and Alvarez FJ
(2011) Early cerebral hemodynamic, metabolic, and histological changes in hypoxic-ischemic fetal lambs during postnatal life. Front. Neurosci. 5:111. doi: 10.3389/fnins.2011.00111

This article was submitted to Frontiers in Neuroscience Methods, a specialty of Frontiers in Neuroscience.

Copyright (c) 2011 Rey-Santano, Mielgo, Gastiasoro, Murgia, Lafuente, Ruiz-delYerro, Valls-i-Soler, Hilario and Alvarez. This is an open-access article subject to a non-exclusive license between the authors and Frontiers Media SA, which permits use, distribution and reproduction in other forums, provided the original authors and source are credited and other Frontiers conditions are complied with. 